Research Article

\title{
Serum Malondialdehyde Level as a Risk Factor for Threatened Abortion
}

\section{Kadar Malondialdehid Serum sebagai Faktor Risiko Terjadinya Abortus Iminens}

\author{
Gusti N Sutama, I Gede P Surya \\ Department of Obstetrics and Gynecology \\ Faculty of Medicine University of Udayana/ \\ Sanglah General Hospital \\ Denpasar
}

\begin{abstract}
Objective: To determine the role of serum malondialdehyde level as a risk factor for threatened abortion.

Method: Our study was a case-control study. We examined 60 pregnant women as our subject, 30 subjects with threatened abortion as cases and 30 subjects with normal pregnancy as control group. Serum levels of malondialdehyde of each woman was examined in the Biochemistry Laboratory Faculty of Medicine Gadjah Mada University in Yogyakarta. We tested the normality of our data using Kolmogorov-Smirnov test, and analysis was then performed using independent sample t-test. To determine the relationship of serum malondialdehyde with threatened abortion, Chi-Square test was used.

Result: From this study we found that the average serum malondialdehyde level in threatened abortion was $1.33 \mp 0.11 \mathrm{nmol} / \mathrm{ml}$, while the average level of serum malondialdehyde in normal pregnancy was $1.03 \mp 0.10 \mathrm{nmol} / \mathrm{ml}$. The analysis using independent t-test shows that the average serum malondialdehyde level on the two groups was significantly different $(p=0.001)$. Based on the cut-off value of $1.12 \mathrm{nmol} / \mathrm{ml}$, we found that the relative risk of threatened abortion is 29.57 times $(95 \% \mathrm{CI}=6.85-127.64, \mathrm{p}=0.001)$ in those with a high level of serum malondialdehyde.
\end{abstract}

Conclusion: The serum malondialdehyde level in threatened abortion was significantly different compared to normal pregnancy. A high level of serum malondialdehyde in pregnancy was a risk factor for threatened abortion.

[Indones J Obstet Gynecol 2015; 1: 11-14]

Keywords: malondialdehyde, normal pregnancy, threatened abortion

\begin{abstract}
Abstrak
Tujuan: Untuk mengetahui peranan kadar malondialdehid pada serum sebagai faktor risiko terjadinya abortus iminens.

Metode: Penelitian ini dilakukan dengan metode kasus-kontrol. Sebanyak 60 ibu hamil diikutsertakan sebagai subjek, 30 orang dengan abortus iminens dalam kelompok kasus dan 30 orang dengan kehamilan normal sebagai kelompok kontrol. Pemeriksaan kadar malondialdehid serum dikerjakan di Laboratorium Biokimia Fakultas Kedokteran Universitas Gadjah Mada Yogyakarta. Uji normalitas data yang terkumpul dilakukan dengan uji Kolmogorov-Smirnov, dan dilakukan analisa data dengan t-test untuk sampel independen. Untuk menentukan risiko terjadinya abortus iminens pada kadar malondialdehid yang tinggi digunakan uji Chi-Square.

Hasil: Pada penelitian ini didapatkan rerata kadar malondialdehid se-

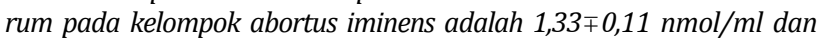
rerata kadar malondialdehid serum pada kehamilan normal adalah

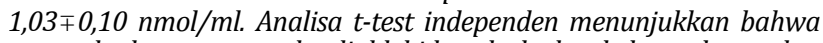
rerata kadar serum malondialdehid pada kedua kelompok tersebut berbeda secara bermakna $(p=0,001)$. Berdasarkan nilai batas 1,12 $\mathrm{nmol} / \mathrm{ml}$, didapatkan bahwa kadar serum malondialdehid yang tinggi meningkatkan risiko terjadinya abortus iminens sebesar 29,57 kali (IK $95 \%=6,85-127,64, p=0,001)$.
\end{abstract}

Kesimpulan: Kadar malondialdehid serum pada abortus iminens memiliki perbedaan yang bermakna jika dibandingkan dengan kadar malondialdehid serum pada kehamilan normal, dan tingginya kadar malondialdehid serum merupakan faktor risiko terjadinya abortus iminens.

[Maj Obstet Ginekol Indones 2015; 1: 11-14]

Kata kunci: abortus iminens, kehamilan normal, malondialdehid

Correspondence: Gusti N Sutama, Department of Obstetrics and Gynecology, Faculty of Medicine University of Udayana/ Sanglah General Hospital, Denpasar, Bali. Mobile: 081337497507, email: gosmansutama@gmail.com

\section{INTRODUCTION}

Abortion is a commonly found obstetric complication in early pregnancy, mostly presenting with vaginal bleeding. Threatened abortion is a situation of threatened pregnancy termination before 20 weeks gestational age or fetal weight reaches 500 grams. ${ }^{1}$ Recently, many researches began studying the role of oxidative stress in abortion pathogenesis. Oxidative stress itself is the imbalance between levels of prooxidative agents (free radical) and antioxidants. ${ }^{2,3}$ Oxidative stress may lead to disorders in placentation. One possible complication resulting from placentation disorder is abortion. It has been hypothesized that the increasing incidence of placentation disorder is correlated with imbalance of free radical levels, which affects placental development and eventually the fetus. ${ }^{4,5}$

Abortion is caused by inadequate trophoblast invasion, followed by trophoblastic oxidative stress, which finally leads to inadequate supply of fetal oxygen and nutrient requirements from the spiral arteries. As pregnancy develops, it is physiological 
that there is increasing energy needs to maintain maternal bodily functions and fetal growth and development, which in the end leads to increasing oxygen needs. Although oxygen is essentially needed in cellular function, a drastic surge in oxygen metabolism will result in toxic substance production known as reactive oxygen species (ROS). The increasing levels of the toxic ROS will bring about cell damage. In order to prevent cellular damage caused by ROS, cells enhance an antioxidant system. When an increase in ROS production causes an imbalance in homeostasis, oxidative stress will lead to impaired cell function or, in the worse case, cellular death. ${ }^{3-5}$ An increase in oxidative stress without increasing antioxidant enzyme levels $\mathrm{Su}-$ peroxide dismutase, gluthatione peroxidase, katalase) cell membrane damage will occur, forming covalent bonds of free radicals and lipid on the cell membrane (peroxidative lipid). Lipid peroxidation is a process where free radicals interact with polyunsaturated fatty acids (PUFA) on the cell membrane and lipoproteins in the cytoplasm. Malondialdehyde acts as a marker of peroxidative lipid production. ${ }^{6}$ The examination of serum malondialdehyde as the marker of lipid peroxidation process is a potential predictive test for abortion. This study aimed to understand the role of serum malondialdehyde level as a risk factor of threatened abortion. In the end, we expect the study to be able to explain the pathophysiology of abortion and eventually find a preventive solution.

\section{METHODS}

We carried out a case-control study. Sixty pregnant women were recruited as samples in this study. Each groups were comprised of 30 women, those with threatened abortion in the case group and those with normal pregnancy in the control group.

The inclusion criteria applied for cases was women with normal pregnancy who experienced a threatened abortion at 8-14 weeks gestational age. Whereas women with normal pregnancy who carried to term were included as controls. Subjects were excluded if they had hydatidiform mole, uterine anatomy anomalies, uterine myoma, and a history of induced abortion.

Serum malondialdehyde level was assessed in Biochemistry Laboratory of the Medical Faculty of Gadjah Mada University, Yogyakarta. The normality of the collected data was assessed using Kolmogorov-Smirnov test, and the difference between both groups was analyzed with independent sample t-test. Chi-square was used to calculate the risk of threatened abortion in women with a high malondialdehyde level.

\section{RESULTS}

This study involved 60 women as samples. Thirty women with threatened abortion were included in the case group and the other 30 women with normal pregnancy were included in the control group. The baseline characteristics of our sample is presented in Table 1.

Table 1. Baseline Characteristics and Average Serum Malondialdehyde Level.

\begin{tabular}{lccc}
\hline \multirow{2}{*}{ Variable } & \multicolumn{2}{c}{ Group } & \multirow{2}{*}{ p } \\
\cline { 2 - 3 } & Case & Control & \\
\hline Age (years) & $27.73 \mp 3.91$ & $26.53 \mp 4.42$ & 0.270 \\
Parity & $1.00 \mp 0.83$ & $0.90 \mp 0.92$ & 0.661 \\
Gestational age (weeks) & $9.43 \mp 1.41$ & $9.87 \mp 1.66$ & 0.279 \\
Malondialdehyde level (nmol/ml) & $1.33 \mp 0.11$ & $1.03 \mp 0.10$ & 0.001 \\
\hline \hline
\end{tabular}


Table 2. Risk of Threatened Abortion in Women with High Serum Malondialdehyde Level

\begin{tabular}{|c|c|c|c|c|c|c|}
\hline & & Case & Control & OR & $95 \%$ CI & $\mathbf{p}$ \\
\hline Serum & High & 27 & 7 & \multirow{2}{*}{29.57} & \multirow{2}{*}{$6.85-127.64$} & \multirow{2}{*}{0.001} \\
\hline Malondialdehyde Level & Normal & 3 & 23 & & & \\
\hline
\end{tabular}

As shown in Table 1, there was no difference between the two groups in terms of age, parity, and gestational age at the time of recruitment. Mean serum malondialdehyde level in the case group was $1.33 \mp 0.11 \mathrm{nmol} / \mathrm{ml}$, while in the control group was $1.03 \mp 0.10 \mathrm{nmol} / \mathrm{ml}$. Furthermore, the average serum malondialdehyde levels was found to be significantly different in the two groups of samples $(\mathrm{p}=0.001)$.

Chi-square was used to investigate the role of serum malondialdehyde on threatened abortion. According to the ROC curve, the cut-off point used for serum malondialdehyde is $1.12 \mathrm{nmol} / \mathrm{ml}$ with sensitivity of $96.7 \%$ and specificity of $80 \%$. The analysis results are presented in Table 2.

Table 2 shows that high serum malondialdehyde level is a risk factor for threatened abortion, with risks increasing as much as 29.57 times in women with serum malondialdehyde levels higher than $1.12 \mathrm{nmol} / \mathrm{ml}$ compared to women with lower serum malondialdehyde (OR $=29.57,95 \% \mathrm{CI}=6.85$ 127.64, $\mathrm{p}=0.001$ ).

\section{DISCUSSION}

The analysis results showed that high serum malondialdehyde level is a risk factor for threatened abortion, with increase in risk as much as 29.57 times with a higher level of serum malondialdehyde ( $p=0.001)$. It is because serum malondialdehyde is formed by lipid peroxidation produced in oxidative stress. ${ }^{6-8} \mathrm{~A}$ high level of malondialdehyde indicates the occurrence of cell membrane oxidation and oxidative stress in threatened abortion. Oxidative stress will in turn lead to impaired placentation. The effect of impaired placentation begins as blood flow disruption in the intervillous area and progresses to pregnancy termination. Abortion itself happens as the result of inadequate trophoblast invasion, and the resulting inadequate supply from the spiral arteries. ${ }^{4,5}$

Measuring the level of free radicals directly is difficult as it is highly reactive. Furthermore, the difficulty of performing direct analysis of free radicals is caused by its instability and its inclination to obtain electrons from other substances in order to stabilize itself. This process occurs in a short time, making it difficult to measure free radicals in its true form. The formation of peroxidative lipid, however, can be used as indirect measurement of free radicals. This is applicable through measurement of peroxidative lipid products marker, such as malondialdehyde. Malondialdehyde is a decomposition product of PUFA peroxidation. ${ }^{6,7}$ Analyzing malondialdehyde means indirectly measuring free radicals and therefore provides an easy method to determine free radical levels. Malondialdehyde provides detection of free radicals in excessively pathological conditions. ${ }^{4,9-11}$ As a result, malondialdehyde is the substance mostly examined since it is believed as a good in vivo peroxidative lipid marker, both in human or animals, which is significantly more accurate and stable then the other markers. Nowadays, malondialdehyde has been used widely as a clinical marker of lipid peroxidation. $6,8,12,13$ The reasons why malondialdehyde is a good oxydative stress biomarker are its formation alongside oxidative stress specifically lipid peroxidation, the ability to measure its serum levels accurately using available methods, its stability in isolated body fluid samples, not being influenced by diurnal variation and dietary fat intake, and the presence of detectable amounts in all body tissues and biological body fluid to determine the reference interval..$^{9}$ Lipid peroxidation is increasing in abortion and pregnancy termination.

Patil reported serum malondialdehyde level in non-pregnant women was $1.19 \mp 0.09 \mathrm{nmol} / \mathrm{ml}$ whilst in pregnant women were $1.42 \mp 0.13 \mathrm{nmol} /$ $\mathrm{ml}, 1.64 \mp 0.14 \mathrm{nmol} / \mathrm{ml}, 1.79 \mp 0.14 \mathrm{nmol} / \mathrm{ml}$ (in the $1^{\text {st }}, 2^{\text {nd }}, 3^{\text {rd }}$ trimester). In Turkey, Ozkaya reported that serum malondialdehyde level in women who suffered spontaneous abortion was higher (66.4干 $13.7 \mathrm{nmol} / \mathrm{ml}$ ) than those in normal pregnancy $(40.3 \mp 16.1 \mathrm{nmol} / \mathrm{ml})$ in the same gestational age. ${ }^{14}$ 


\section{CONCLUSION}

The serum malondialdehyde level in threatened abortion is significantly different than those in normal pregnancy. A higher level of serum malondialdehyde was found to be a risk factor for threatened abortion.

\section{REFERENCES}

1. Cunningham FG, Leveno KJ, Gant NF, et al. (Eds.) Williams Obstetrics. 23 ${ }^{\text {rd }}$ ed. New York: McGraw Hill; 2010: 950-75.

2. Eberhardt MK. Reactive Oxygen Metabolites: Chemistry and Medical Consequences. $2^{\text {nd }}$ ed. Washington DC: CRC Press; 2000: 174-85.

3. Agarwal A, Gupta S, Sharma RK. Role of oxidative stress in female reproduction. Reprod Biol Endocrinol 2005; 3: 2835.

4. Jauniaux E, Hempstock J, Greenwold N, et al. Trophoblastic oxidative stress in relation to temporal and regional differences in maternal placental blood flow in normal and abnormal early pregnancies. Am J Pathol 2003; 162: 115-45.

5. Aksoy AN, Aksoy H, Öztürk N, Bulut C. Erythrocyte TAO and TBARS levels in patients who suffered missed abortion. Turk J Med Sci 2009; 39(6): 881-5.

6. Winarsi H. Antioksidan Alami dan Radikal Bebas. Yogyakarta: Kanisius; 2007: 50-5.
7 Patil SB, Kodliwadmath MV, Kodliwadmath SM. Correlation between lipid peroxidation and non-enzymatic antioxidants in pregnancy induced hypertension. Ind J Clin Biochemist 2008; 23(1): 45-8.

8. Niki E. Lipid peroxidation: physiological levels and dual biological effects. Free Radical Biol Med 2009; 47(5): 469-84.

9. Llurba E, Gratacós E, Martín-Gallán P, et al. A comprehensive study of oxidative stress and antioxidant status in preeclampsia and normal pregnancy. Free Radical Biol Med 2004; 37(4): 557-70.

10. Patil SB, Kodliwadmath MV, Kodliwadmath SM. Study of oxidative stress and enzymatic antioxidant in normal pregnancy. Ind J Clin Biochemist 2007; 22(1): 135-7.

11. Paszkowski T, Lagod L, Sikorsi R, et al. The role of oxidative stress in the pathogenesis of early pregnancy loss. Poland J Gynecol Invest 2001; 3(3): 135-8.

12. Jauniaux E, Poston L, Burton GJ. Placental-related diseases of pregnancy: involvement of oxidative stress and implications in human evolution. Hum Reprod 2006; 14: 747-55.

13. Jauniaux E, Watson AL, Hempstock J, et al. Onset of maternal arterial blood flow and placental oxidative stress. A possible factor in human early pregnancy failure. Am J Pathol 2000; 157: 2111-42.

14. Ozkaya O, Mekin S, Hakan K. Serum malondialdehyde, erythrocyte glutathione peroxidase, and erythrocyte superoxide dismutase levels in women with early spontaneous abortion accompanied by vaginal bleeding. Med Sci Monit 2008; 14: 47-51. 